\title{
Bioremediation of heavy metal-contaminated effluent using optimized activated sludge bacteria
}

\author{
Ebtesam El. Bestawy • Shacker Helmy • \\ Hany Hussien • Mohamed Fahmy • Ranya Amer
}

Received: 14 October 2011/ Accepted: 3 December 2012/Published online: 16 December 2012

(C) The Author(s) 2012. This article is published with open access at Springerlink.com

\begin{abstract}
Removal of heavy metals from contaminated domestic-industrial effluent using eight resistant indigenous bacteria isolated from acclimatized activated sludge was investigated. Molecular identification using 16S rDNA amplification revealed that all strains were Gram-negative among which two were resistant to each of copper, cadmium and cobalt while one was resistant to each of chromium and the heavy metal mixture. They were identified as Enterobacter $\mathrm{sp} .\left(\mathrm{Cu}_{1}\right)$, Enterobacter $\mathrm{sp} .\left(\mathrm{Cu}_{2}\right)$, Stenotrophomonas sp. $\left(\mathrm{Cd}_{1}\right)$, Providencia sp. $\left(\mathrm{Cd}_{2}\right)$, Chryseobacterium sp. $\left(\mathrm{Co}_{1}\right)$, Comamonas sp. $\left(\mathrm{Co}_{2}\right)$, Ochrobactrum sp. $(\mathrm{Cr})$ and Delftia sp. $\left(\mathrm{M}_{1}\right)$ according to their resistance pattern. Strains $\mathrm{Cu}_{1}, \mathrm{Cd}_{1}, \mathrm{Co}_{2}$ and $\mathrm{Cr}$ were able to resist $275 \mathrm{mg} \mathrm{Cu} / \mathrm{l}$,
\end{abstract}

E. El. Bestawy $(\bowtie) \cdot$ S. Helmy

Department of Environmental Studies, Institute

of Graduate Studies and Research, Alexandria University,

163 Horria Ave. El-Shatby, P.O. Box 832, Alexandria, Egypt

e-mail: ebtesamelbestawy@yahoo.com

S. Helmy

e-mail: shackerh@yahoo.com

Present Address:

E. El. Bestawy

Department of Life Sciences, Faculty of Science,

King Abdul Aziz University, P.O. Box 42805,

Jeddah 21551, Kingdom of Saudi Arabia

H. Hussien · M. Fahmy $\cdot$ R. Amer

Department of Environmental Biotechnology,

City for Scientific Research and Technology Application,

P.O. Box 21934, Alexandria, Egypt

e-mail: hhussein66@yahoo.com

M. Fahmy

e-mail: mohamedfahmy73@yahoo.com

R. Amer

e-mail: ranyaamer@yahoo.com; r.amer@mucsat.sci.eg
$320 \mathrm{mg} \mathrm{Cd} / 1,140 \mathrm{mg} \mathrm{Co} / \mathrm{l}$ and $29 \mathrm{mg} \mathrm{Cr} / \mathrm{l}$ respectively. The four resistant strains were used as a mixture to remove heavy metals (elevated concentrations) and reduce the organic load of wastewater effluent. Results revealed that using the proposed activated sludge with the resistant bacterial mixture was more efficient for heavy metal removal compared to the activated sludge alone. It is therefore recommended that the proposed activated sludge system augmented with the acclimatized strains is the best choice to ensure high treatment efficiency and performance under metal stresses especially when industrial effluents are involved.

Keywords Acclimatization · Activated sludge · Bioremediation · Domestic · Heavy metals · Industrial wastewater

\section{Introduction}

Heavy metals are considered one of the most common and hazardous pollutants in industrial effluents that might cause serious problems to the sewage network pipelines. The deleterious effects of heavy metals on biological processes are complex and generally related to species, solubility and concentration of the metal and the characteristics of the influent, such as $\mathrm{pH}$, as well as presence and concentration of other cations and/or molecules and suspended solids (Gikas 2008). Metal toxicity results from alterations in the conformational structure of nucleic acids, proteins or by interference with oxidative phosphorylation and osmotic balance (Yaoa et al. 2008). The most common mechanisms by which metals are eliminated from wastewater treatment processes depend on precipitation, adsorption to suspended solids during primary sedimentation or adsorption to extracellular polymers (Qodah 2006). Use of bio-adsorbents 
such as bacteria, fungi, algae and some agricultural wastes that emerged as an eco-friendly, effective and low cost material option could offer potential inexpensive alternatives to the conventional adsorbents (Valls and Lorenzo 2002). Different species of Aspergillus, Pseudomonas, Sporophyticus, Bacillus, Phanerochaete, etc., have been reported as efficient chromium and nickel reducers. The response of microorganisms towards toxic heavy metals is very important for reclamation of polluted sites (Congeevaram et al. 2007).

Adsorption of heavy metals on the sludge surface is usually attributed to the formation of complexes between metals and carboxyl, hydroxyl and phenolic surface functional groups of the extracellular polymeric substances (EPS) produced by many different species of bacteria isolated from activated sludge (Yuncu et al. 2006). EPS are metabolic products of bacteria result from the organic matter of the effluent and from microbial lysis or hydrolysis. They serve as a protective barrier for cells against the harsh external environment and play a crucial role in sequestration and biosorption of metal ions as well as ions which constitute metabolic elements for bacteria. Metal biosorption performance depends on external factors, such as $\mathrm{pH}$, other ions in bulk solutions (which may be in competition), organic material in bulk solution and temperature (Comte et al. 2007).

Identification of sludge bacteria that are adapted to the new toxic metal environment provide efficient potential candidates for heavy metal bioremoval from contaminated media. Because of its size ( 1,500 base pairs), the $16 \mathrm{~S}$ rRNA gene is the most widely used sequence in bacterial identification (Weisburg et al. 1991; Drancourt et al. 2000). Segments from these genes can be easily amplified by PCR using universal primers and sequenced. Sequence comparison of 16S rRNA has been used as a powerful tool for establishing phylogenetic and evolutionary relationships among organisms (Amer 2003).

Alexandria is the second largest industrial city in Egypt where more than $40 \%$ of the industrial activity localized. In Alexandria, industrial effluents are mixed with domestic sewage and discharged into the main sewage network (Hussein 1999). The aim of the present study was to isolate and identify heavy metal resistant bacteria from acclimatized activated sludge to be used for remediation of heavy metal contaminated wastewater at their highest expected levels.

\section{Materials and methods}

Sampling and pre-treatment

Activated sludge samples were obtained from the aeration tank of the activated sludge unit at Damanhore Wastewater
Treatment Plant located in the North West side of Egypt. Prior to use, sludge was pre-treated by allowing the sludge to settle at room temperature followed by decanting the supernatant and replacement with synthetic wastewater with aeration to maintain dissolved oxygen above $4 \mathrm{mg} / \mathrm{l}$. After $24 \mathrm{~h}$, aeration was stopped and the mixture was allowed to settle, then the supernatant was decanted and fresh synthetic wastewater was added to provide the same original volume. The procedure of settling, decanting, addition of new effluent and nutrients was repeated at 24-h interval until the desired acclimation time (approximately 1 month) had been achieved.

Heavy metal determination

Four heavy metals $(\mathrm{Cu}, \mathrm{Cd}, \mathrm{Cr}$ and $\mathrm{Co})$ in the wastewater and sludge were determined using Atomic Adsorption Spectrophotometry (Perkin Elmer) after digestion with microwaves digester following the manual instructions with the addition of nitric acid, hydrofluoric acid and hydrogen peroxide for sample digestion (Costley and Wallis 2001; Borowski 2004).

\section{Measurement of dehydrogenase activity (DHA)}

Dehydrogenase activity was determined using method described by Weddle and Jenkins (1971). Triphenyl tetrazolium chloride (TCC) and sodium sulfate solutions (5\%) were prepared in distilled water. One milliliter of TCC, $10 \mathrm{ml}$ liquor or cell suspension and 3 drops of $\mathrm{NaSO}_{3}$ were placed in centrifuge tube and shaken at $30{ }^{\circ} \mathrm{C}$ for $1 \mathrm{~h}$ in dark. This was followed by centrifugation for $5 \mathrm{~min}$; the color of the supernatant was determined using spectrophotometer at wavelength $480 \mathrm{~nm}$. Inhibition of the bacteria and consequently the activated sludge activity were determined according to the following equation:

$\operatorname{Inhibition}(\%)=\left[\left(I_{0}-I\right) / I_{0}\right] \times 100$

Where $I_{0}$ represents intensity of the control without treatment and $I$ represents intensity of sample after treatment with heavy metal (Weddle and Jenkins 1971; Shim et al. 2003).

Isolation of heavy metal-tolerant bacteria

Tolerant bacterial isolates were collected from five different acclimatized activated sludge batch reactors treated by synthetic wastewater (Table 1) with elevated levels of $\mathrm{Cu}$, $\mathrm{Cd}, \mathrm{Co}, \mathrm{Cr}$ (prepared as $10 \%$ stock solutions of $\mathrm{CuSO}_{4}$, $\mathrm{CdCl}_{2} \cdot \mathrm{H}_{2} \mathrm{O}, \mathrm{K}_{2} \mathrm{Cr}_{2} \mathrm{O}_{7}, \mathrm{CoCl}_{2} \cdot 6 \mathrm{H}_{2} \mathrm{O}$ salts) and metal mixture (El. Bestawy et al. 2012) as described by Özbelge et al. (2005). Tolerant bacteria were isolated from the final stage of the metal enrichment experiment at all reactors. 
Table 1 Composition of the concentrated synthetic wastewater

\begin{tabular}{llc}
\hline Serial & Constituents & Concentration $(\mathrm{g} / \mathrm{l})$ \\
\hline 1 & Tripton & 122.1 \\
2 & $\mathrm{NaCl}$ & 40.7 \\
3 & $\mathrm{Na}_{2} \mathrm{SO}_{4}$ & 4.46 \\
4 & $\mathrm{~K}_{2} \mathrm{H}_{2} \mathrm{PO}_{4}$ & 4.46 \\
5 & $\mathrm{MgCl}_{2} \cdot 6 \mathrm{H}_{2} \mathrm{O}$ & 0.37 \\
6 & $\mathrm{CaCl}_{2} \cdot 2 \mathrm{H}_{2} \mathrm{O}$ & 0.37 \\
7 & $\mathrm{MnSO}_{4}$ & 0.57 \\
8 & $\mathrm{H}_{2} \mathrm{MoO}_{4}$ & 0.31 \\
9 & $\mathrm{NaOH}_{1}$ & 0.08 \\
10 & $\mathrm{ZnSO}_{4}$ & 0.46 \\
11 & $\mathrm{CoSO}_{4}$ & 0.49 \\
12 & $\mathrm{CuSO}_{4}$ & 0.76 \\
\hline
\end{tabular}

$10 \mathrm{ml}$ of concentrated synthetic wastewater were added to each $1,000 \mathrm{ml}$ of deionized waster

One-milliliter liquor from each reactor was used to inoculate liquid Luria-Bertani (LB) medium containing the investigated heavy metal (sterilized by filtration) in that reactor. Heavy metal concentrations used during bacterial isolation were $15,100,40$ and $40 \mathrm{mg} / \mathrm{l}$ for the individual $\mathrm{Cu}, \mathrm{Cr}, \mathrm{Cd}$ and $\mathrm{Co}$, respectively. While a mixture of $\mathrm{Cu}$, $\mathrm{Cr}, \mathrm{Cd}$ and $\mathrm{Co}$ at 2, 10, 10 and $10 \mathrm{mg} / \mathrm{l}$ respectively was used for isolation of strains with multiple accumulation ability. After $24 \mathrm{~h}$ incubation at $30{ }^{\circ} \mathrm{C}, 100 \mu \mathrm{l}$ of the grown culture was transferred into $10-\mathrm{ml}$ fresh LB medium containing the same metal concentration and left for another $24 \mathrm{~h}$ under the same conditions. The highest metal concentration reduced the activated sludge activity by $50 \%$ was amended in Petri dish containing $20 \mathrm{ml}$ sterile LB agar and mixed well. $100 \mu \mathrm{l}$ of the grown culture was spread on the surface of the plate and incubated for $24 \mathrm{~h}$ at $30^{\circ} \mathrm{C}$. Large identical colonies from each plate were picked out and cultured for purification and identification.

\section{Molecular identification}

Total genomic DNA was extracted from $5 \mathrm{ml}$ overnight LB culture of the purified isolates (Sambrook et al. 1989). PCR was performed in a light cycler Eppendorf PCR machine. A 1,300-bp fragment was obtained by PCR amplification of the 16S rDNA gene (Ausubel et al. 1999) using the primers B341F (5'-CCTACGGGA GGCAGC) and 1392R (5'-ACG GGCGGTG TGTRC- $3^{\prime}$ ). The PCR mixture was composed of $100 \mathrm{ng}$ of genomic DNA, $30 \mathrm{pmol}$ of each primer, $200 \mu \mathrm{M}$ of dNTPs, $1 \mathrm{U}$ of Taq polymerase and $10 \mu \mathrm{l}$ of $10 \mathrm{X}$ PCR buffer, the reaction volume was adjusted to $100 \mu \mathrm{l}$ in $0.5 \mathrm{ml}$ eppendorf tube. The PCR amplification conditions were performed by an initial denaturation step at $94{ }^{\circ} \mathrm{C}$ for $10 \mathrm{~min}$ followed by 30 denaturation cycles at $94{ }^{\circ} \mathrm{C}$ for $1 \mathrm{~min}$, annealing at $60^{\circ} \mathrm{C}$ for $1 \mathrm{~min}$ and an extension at
$72{ }^{\circ} \mathrm{C}$ for $1 \mathrm{~min}$ followed by a final extension step at $72{ }^{\circ} \mathrm{C}$ for $10 \mathrm{~min}$. Amplicons of $16 \mathrm{~S}$ rDNA were purified using PCR purification kit (QIAGEN). Each of these purified products was sequenced by the chain terminator method (ABI 3130XL system, DNA technology, Denmark) using the two corresponding PCR primers separately. The resulted DNA sequences were phylogenetically analyzed using the BLAST search program. Multiple sequence alignment and molecular phylogeny were performed using BioEdit software (Hall 1999).

Screening for heavy metal resistance pattern

Effect of the individual and mixed tested metals on the growth (measured as optical density, OD at $600 \mathrm{~nm}$ ) and dehydrogenase activity of each of the resistant strains was investigated at elevated metal concentrations compared to their controls. An overnight culture of each strain was inoculated in 20-ml LB medium supplemented with definite concentrations of the corresponding heavy metals and incubated for $24 \mathrm{~h}$ under the previously mentioned conditions. Concentrations of the tested metals (not shown) were calculated according to the IC50 which is also included in the screening test. Concentrations of heavy metal mixtures were calculated by dividing the growth IC50 of each heavy metal by 4 and two higher and two lower concentrations were applied for screening bioassay.

\section{Treatability studies}

The most efficient strains for metal removal were selected based on the resistance screening bioassays and manipulated in activated sludge treatment of mixed domesticindustrial wastewater contaminated with heavy metals and organic matter. The acclimatized sludge was prepared by centrifugation to remove the supernatant which was replaced by wastewater. The resistant strain for each investigated metal was seeded individually in LB-medium and incubated at $30{ }^{\circ} \mathrm{C}$ and $200 \mathrm{rpm}$ for $24 \mathrm{~h}$. Cultures were centrifuged and the supernatants were replaced with wastewater and used as inocula for batch reactors for the treatability study with moderate concentrations of heavy metals. Three sets of 500-ml reactors were used to compare the removal efficiencies of the sludge, bacterial strains and mixture of both. Each set contained four different concentrations (not shown) of the heavy metals with initial COD of $1,400 \mathrm{mg} / \mathrm{l}$ as following:

1. The first set consists of $200 \mathrm{ml}$ of sludge with different concentrations of the investigated heavy metals.

2. The second set consists of $200 \mathrm{ml}$ of bacterial culture only with different concentrations of the investigated heavy metals. 
3. The third set consists of $100 \mathrm{ml}$ of sludge and $100 \mathrm{ml}$ of bacterial culture with different concentrations of the investigated heavy metals.

Heavy metal removal per unit biomass was determined using the following equation:

$M$ uptake $/ \mathrm{g}=[M($ Inf. $)-M($ Eff. $)] / M($ MLSS $)$

where $M=$ uptake/g: heavy metal removed per unit mass of biomass,

$M$ (Inf.) = the initial heavy metal concentration in the influent,

$M$ (Eff.) the final metal concentration after treatment,

MLSS: Biomass concentration in gram

\section{Results}

Isolation and molecular identification of metal resistantsludge bacteria

A total of eight strains representing morphologically different bacterial colonies were isolated and purified. Two showed resistance to copper $\left(\mathrm{Cu}_{1}\right.$ and $\left.\mathrm{Cu}_{2}\right)$, two for cadmium $\left(\mathrm{Cd}_{1}\right.$ and $\left.\mathrm{Cd}_{2}\right)$, two for cobalt $\left(\mathrm{Co}_{1}\right.$ and $\left.\mathrm{Co}_{2}\right)$, one for chromium $(\mathrm{Cr})$ and the heavy metal mixture resistant strain $\left(\mathrm{M}_{1}\right)$. PCR products of the chromosomal DNA extracts of the resistant isolates were purified, sequenced and aligned against the $16 \mathrm{~S}$ rDNA sequences of the ribosomal database project http://www.cme.msu. edu/RDP/html/index/html (Maidak et al. 1994; Rainey et al. 1996). Sequences were deposited in GenBank for obtaining accession numbers. The Phylogenetic relationship among the tested isolates and the closely related species (Fig. 1) was analyzed using multi-sequence alignment program (BioEdit Sequence Alignment Editor). Accession numbers and similarity of the tested isolates to the related species are presented in Table 2. It is well documented that both Gram-positive and Gram-negative bacteria are ubiquitous in nature with highly resistant anionic cell walls. This anionic cell wall can fix metal and provide sites for nucleation and growth of minerals, a property that has been the basis for many heavy metal removals using bacterial biomass (Kelly et al. 2004).

Heavy metal resistance and/or sensitivity of the sludge bacteria

Resistance and/or sensitivity of the acclimatized sludge bacteria towards the investigated metals (individuals or mixture) were determined in terms of growth (OD) and dehydrogenase activity to select the most efficient for treatability study.
Effect of individual metals

Comparing data of the individual effects of the four tested metals on the acclimatized strains (Fig. 2) revealed the following points:

1. IC50 of all the tested metals that induced $50 \%$ reduction in the growth of all the investigated strains was higher than that induced $50 \%$ reduction in their DHA. This indicates that tested metal could inhibit the enzyme activity much higher than its inhibition to the growth because dehydrogenase activity is a direct reflection of microbial activity (Gong 1997; Mathew and Obbard 2001) and metal toxicity (Aoyama and Nagumo 1997; Kelly and Tate 1998; Nweke et al. 2006).

2. IC50 of each metal depends mainly on the microbial species as well as acclimatization period, culturing or operation conditions, nutrient status and the presence of other inhibitors. Isolated strains $\mathrm{Cu}_{1}, \mathrm{Cd}_{1}, \mathrm{Co}_{2}$ and $\mathrm{Cr}$ had the highest ability to grow individually in the presence of $\mathrm{Cu}, \mathrm{Cd}, \mathrm{Co}$ and $\mathrm{Cr}$ with IC50 of 275, 320, 140 and $29 \mathrm{mg} / \mathrm{l}$, respectively.

3. Although possessing multiple resistances, most of the acclimated strains exhibited their highest resistance with their corresponding metals. For example Enterobacter $\mathrm{sp} .\left(\mathrm{Cu}_{1}\right.$ and $\left.\mathrm{Cu}_{2}\right)$ showed the highest $\mathrm{OD}(275$ and 190 , respectively) with copper that declined to 190 and 46, respectively with $\mathrm{Cd}$ followed by more toxicity with Co and Cr. Similarly, Stenotrophomonas sp. $\left(\mathrm{Cd}_{1}\right)$ and Providencia sp. $\left(\mathrm{Cd}_{2}\right)$ also showed high resistance to Cd (OD 320 and 260, respectively; DHA 50 and 15 , respectively) compared to their resistance pattern for other metals.

4. Ochrobactrum sp. $(\mathrm{Cr})$ isolated from activated sludge amended with chromium was more sensitive to chromium (OD 29) compared to copper and cadmium (OD 75 and 150, respectively). On contrary Ochrobactrum sp. strain CSCR-3 isolated from chromium landfills was able to tolerate and reduce $\mathrm{Cr}$ VI to $\mathrm{Cr}$ III in cultures containing $800 \mathrm{mg} / \mathrm{l} \mathrm{Cr}$ (He et al. 2009). This is mainly attributed to factors controlling resistance and/or toxicity of metals of which microbial species and the form of the metal are key factors (Gikas and Romanos 2006).

Results confirmed that gradual increase of the applied metals produced generations with high metal resistance range that can be efficiently used in decontamination purposes. These results are in agreement and supported by other studies. For example a Cd-resistant Stenotrophomonas sp. showed resistance to Se (Antonioli et al. 2007) and $\mathrm{Cu}$ (Zaki and Farag 2010); a Cd-resistant Providencia sp. showed very high resistance $(1,000-1,500 \mathrm{mg} / \mathrm{l})$ to $\mathrm{Cd}$, 
A

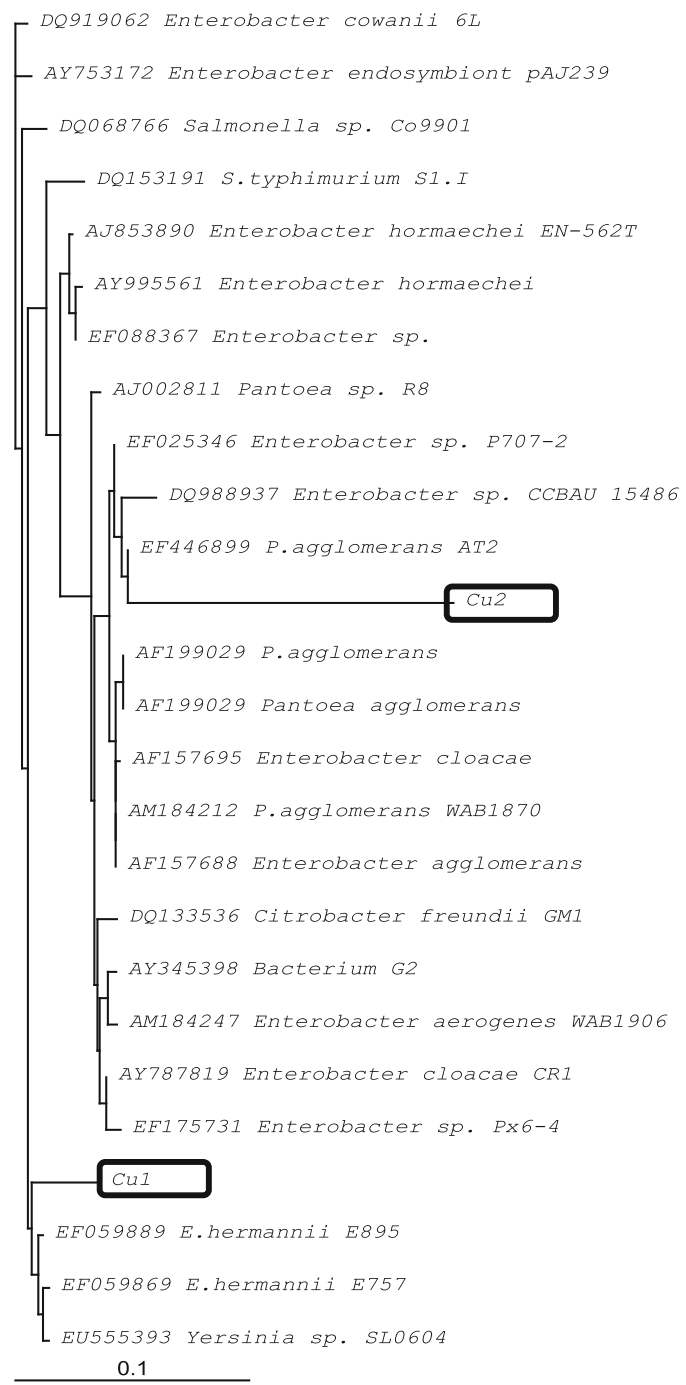

B

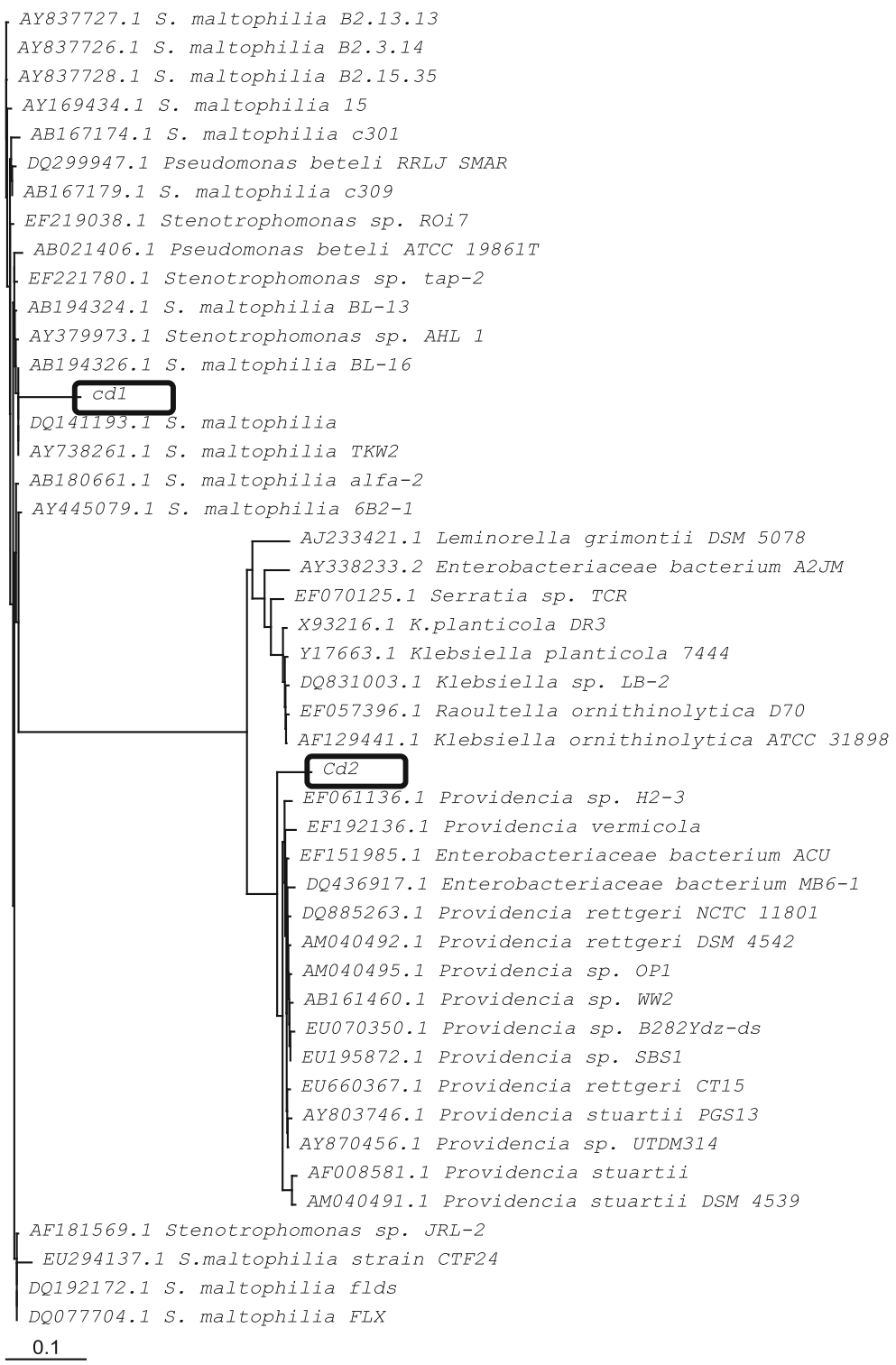

Fig. 1 Phylogenetic relationships of the isolated metal resistant bacteria generated using tree view program

Cr, Ni, Co and Zn (Thacker et al. 2006) and Pseudomonas with multi resistance to $\mathrm{Cr}, \mathrm{Cu}, \mathrm{Cd}$ and $\mathrm{Ni}$ (Kelly et al. 2004). In addition, Comamonas sp. $\left(\mathrm{Co}_{2}\right)$ that showed moderate growth and DHA activity (140 and 82, respectively) when cultivated with $50 \mathrm{mg} / \mathrm{l}$ cobalt was found containing plasmid encoding cobalt and nickel resistance (Siunova et al. 2009).

According to their average DHA (reflecting their resistance) against the individual metals, acclimatized bacteria can be arranged in the following order from the highly resistant to the highly sensitive $\mathrm{Cd}_{1}>\mathrm{Co}_{2}>\mathrm{Cr}>$ $\mathrm{Cu}_{2}>\mathrm{Cu}_{1}>\mathrm{M}_{1}>\mathrm{Cd}_{2}$. Therefore, Stenotrophomonas sp. $\left(\mathrm{Cd}_{1}\right)$ represents the highest DHA activity indicating the lowest toxic effects upon exposure to individual metals.

\section{Effect of mixed metals}

The final stage in the screening process was to investigate each of the acclimatized strain isolated against mixture of the tested heavy metals $(\mathrm{Cu}, \mathrm{Cd}, \mathrm{Co}$ and $\mathrm{Cr})$ based on its IC50 concentrations obtained in the previous stage. The concentration of each heavy metal for each strain was calculated by dividing its growth IC 50 by 4 , and then two higher and two lower concentrations were used for the screening process (i.e., five mixtures with elevated metals concentration). Applying the investigated metals as mixtures led to completely different responses from the investigated acclimatized strains (Fig. 3). Results revealed the following points: 


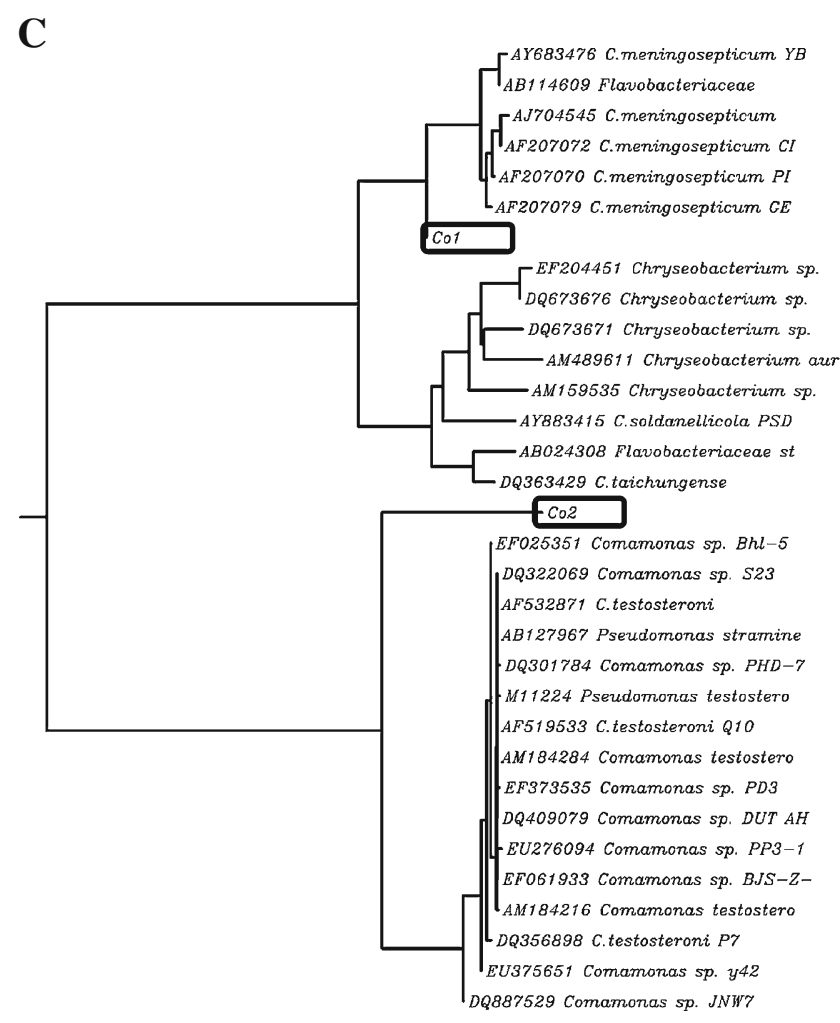

Fig. 1 continued

1. As with the individual metals, IC50 of all tested metals, those induced $50 \%$ reduction in the growth, of all the investigated strains were higher than those induced $50 \%$ reduction in their DHA, indicating that metal inhibits enzyme activity much higher than growth.

2. As expected, tolerance of the investigated strains was reduced dramatically towards the tested metal mixtures compared to their individual application. This was shown by the growth IC50 recorded 70, 81.25, 43.75 and $12.5 \mathrm{mg} / \mathrm{l}$ for strains $\mathrm{Cu}_{1}, \mathrm{Cd}_{2}, \mathrm{Co}_{2}$ and $\mathrm{Cr}$, respectively in the metal mixtures compared to 275 , 320,140 and $29 \mathrm{mg} / \mathrm{l}$, respectively when grown individually in their corresponding metals.

3. IC50 of DHA of the isolated strains $\mathrm{Cu}_{1}, \mathrm{Cu}_{2}, \mathrm{Cd}_{1}$, $\mathrm{Cd}_{2}, \mathrm{Co}_{2}, \mathrm{Cr}$ and $\mathrm{M}$ against the tested metals $(\mathrm{Cu}, \mathrm{Cd}$, $\mathrm{Co}$ and $\mathrm{Cr}$ ) recorded 35, 20, 2 and 2; 37.5, 18.75, 11.25 and $1.5 ; 5,20,7.5$ and $1 ; 5,16.25,1.75$ and $1.75 ; 8$, $12.5,17.5$ and 2; 10, 20, 3.5 and 5; and finally 18, 18, 30 and $6 \mathrm{mg} / \mathrm{l}$ respectively (Fig. 3).

4. According to their average DHA against the mixed metals, acclimatized bacteria can be arranged in the following order from the highly resistant to the highly sensitive $\mathrm{M}>\mathrm{Cu}_{2}>\mathrm{Cu}_{1}>\mathrm{Co}_{2}>\mathrm{Cr}>\mathrm{Cd}$. Delftia sp. exhibited the highest resistance to the mixture of

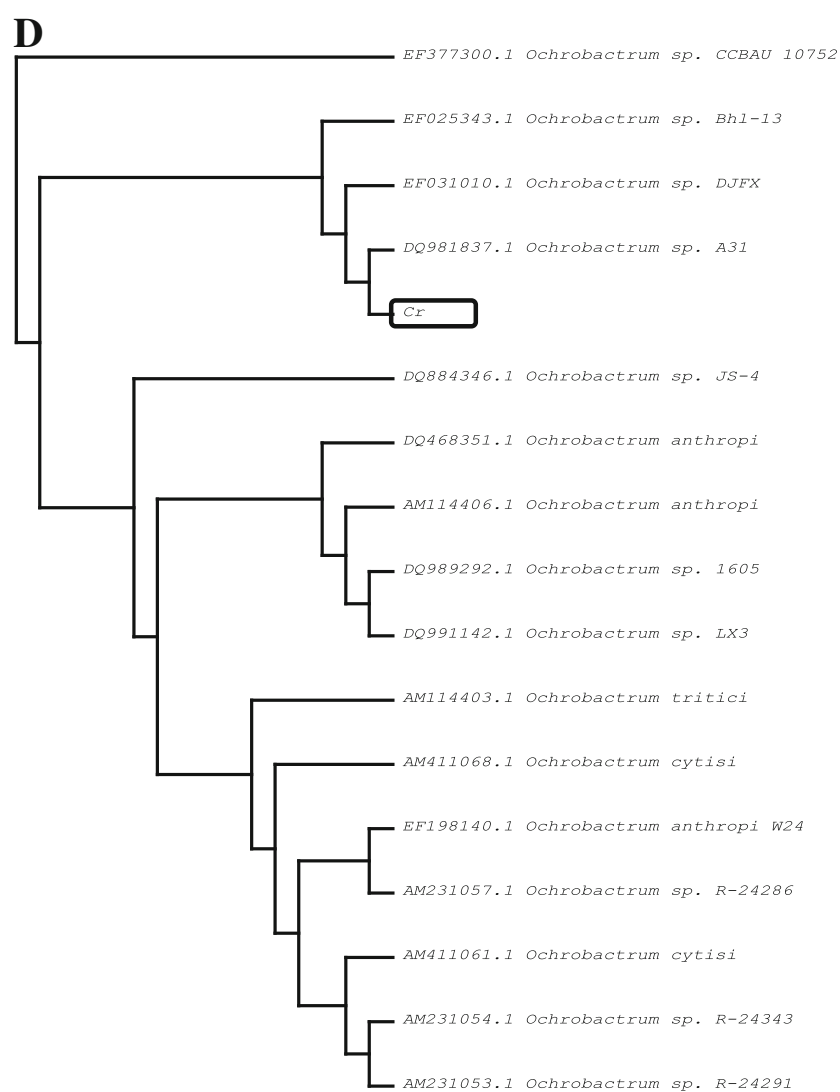

the investigated metals due to the adaptation acquired during the acclimatization process when grown in the presence of heavy metal mixture.

These results are consistent with those of Jackson et al. (2009) who reported a multiple heavy metal resistance of Delftia sp. when used within a consortium for bioremediation of River Plankenburg water in South Africa contaminated with aluminum, nickel, copper and manganese due to the presence of highly incidence plasmids (Zolgharnein et al. 2007).

\section{Treatability bioassay}

Three parallel strategies were used to evaluate the remediation capability of the proposed system towards heavy metal- and organic matter-contaminated wastewater. Treatment technologies included the proposed activated sludge unit amended with the acclimatized bacterial strains (ASBS), the plain activated sludge unit (AS) and the acclimatized bacterial cultures (BS) alone represented by $\mathrm{Cu}_{1}, \mathrm{Cd}_{1}, \mathrm{Co}_{2}$ and $\mathrm{Cr}$. The performance of the three procedures was evaluated to determine the most efficient application. Also a comparison was made between the removal efficiency of the contaminated metals and the 


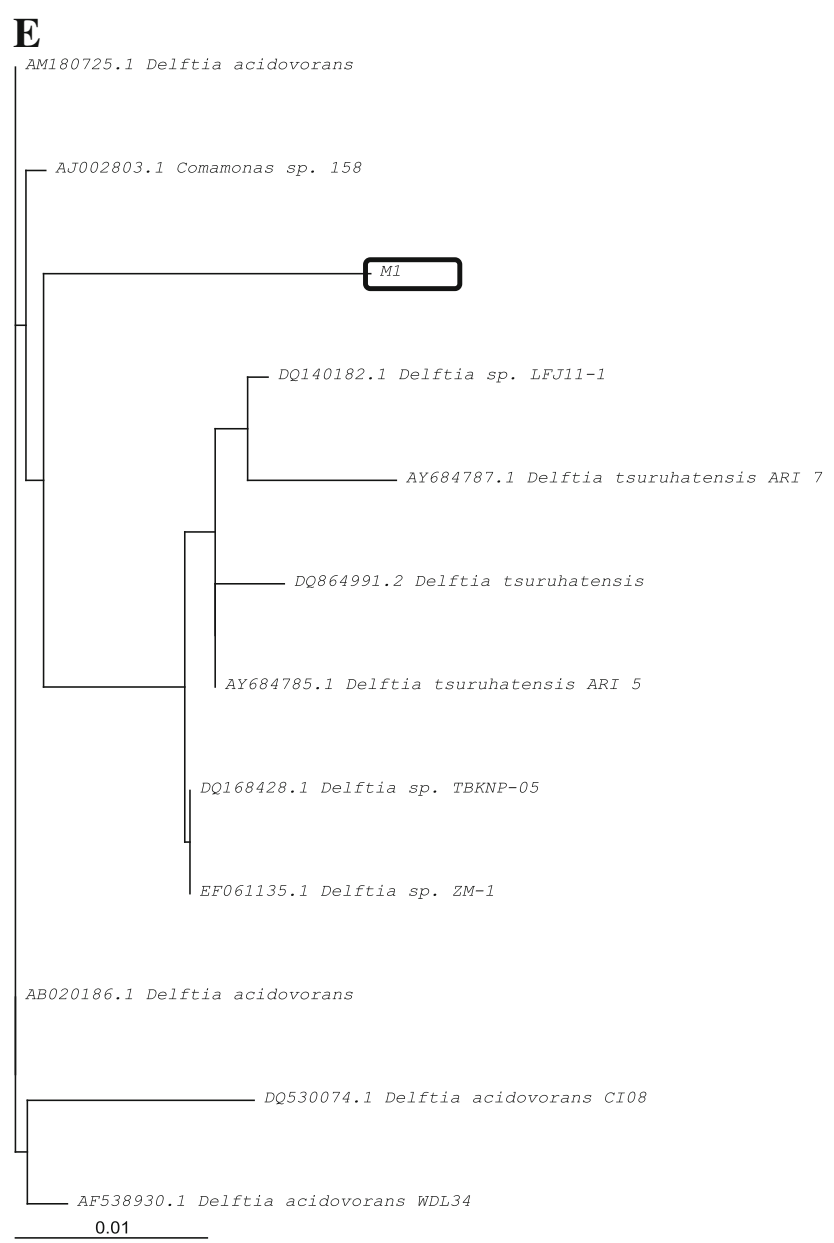

Fig. 1 continued

Table 2 Resistant isolates' accession numbers and their similarity to the related species

\begin{tabular}{llll}
\hline Isolate & Accession no. & Similar Strain & Similarity (\%) \\
\hline $\mathrm{Cd}_{1}$ & FJ205387 & Stenotrophomonas sp. & 99 \\
$\mathrm{Cd}_{2}$ & FJ205388 & Providencia sp. & 98 \\
$\mathrm{Cu}_{1}$ & FJ205389 & Enterobacter sp. & 98 \\
$\mathrm{Cu}_{2}$ & FJ205390 & Enterobacter sp. & 99 \\
$\mathrm{Co}_{1}$ & FJ205391 & Chryseobacterium $\mathrm{sp}$. & 98 \\
$\mathrm{Co}_{2}$ & FJ205392 & Comamonas sp. & 97 \\
$\mathrm{Cr}$ & FJ205394 & Ochrobactrum sp. & 98 \\
$\mathrm{M}_{1}$ & FJ205393 & Delftia sp. & 99 \\
\hline
\end{tabular}

organic matter load (as COD). Four different concentrations of each heavy metal were investigated in the three planned treatment procedures and the removal was determined after $24 \mathrm{~h}$ exposure.

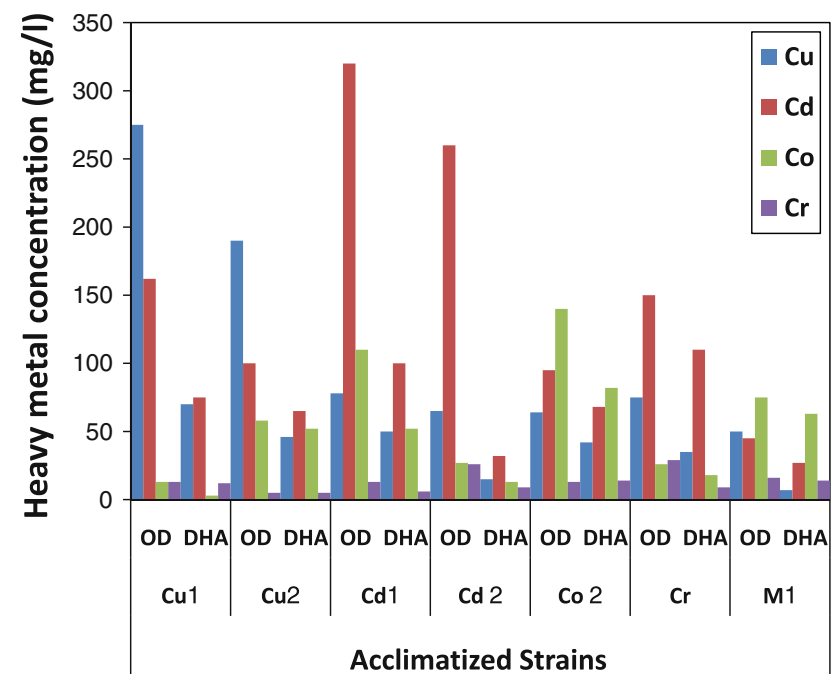

Fig. 2 IC50 for the growth (OD) and dehydrogenase activity (DHA) of the acclimatized strains after 24-h exposure to individual heavy metals: $\mathrm{Cu}$ copper, $\mathrm{Cd}$ cadmium, $\mathrm{Co}$ cobalt, $\mathrm{Cr}$ chromium

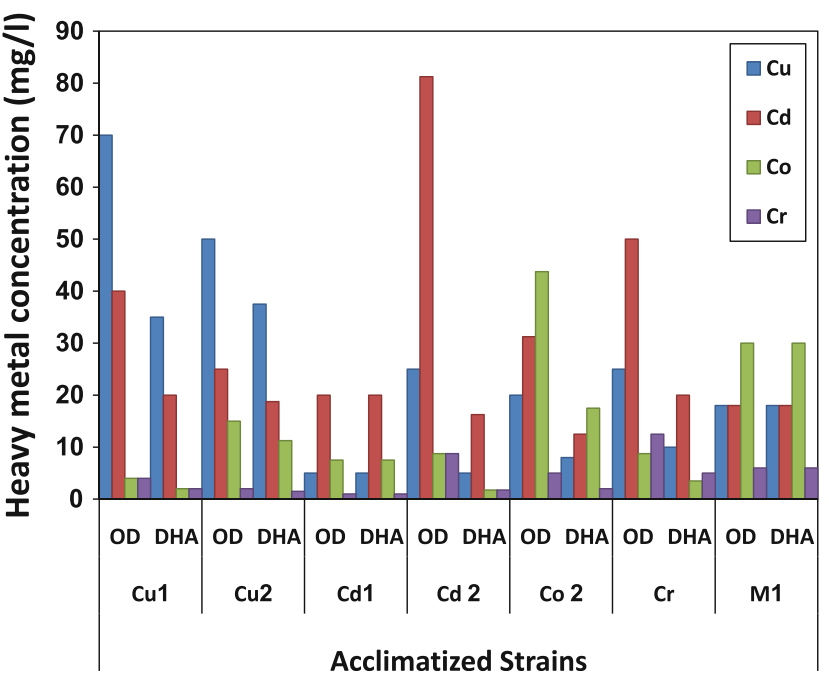

Fig. 3 IC50 for the growth (OD) and dehydrogenase activity (DHA) of the acclimatized strains after $24 \mathrm{~h}$ exposure to the heavy metals in mixture: $\mathrm{Cu}$ copper, $\mathrm{Cd}$ cadmium, $\mathrm{Co}$ cobalt, $\mathrm{Cr}$ chromium

Treatment of wastewater effluent under individual metal stresses

Wastewater collected from the Western Wastewater Treatment Plant (WWTP), Alexandria was subjected to $24 \mathrm{~h}$ treatment using ASBS, AS and BS technologies after the addition of four elevated concentrations of individual heavy metals (20-200 mg/l for each of $\mathrm{Cu}, \mathrm{Cd}$ and $\mathrm{Co}$ and 20-300 mg/l for Cr). Results achieved (Figs. 4 and 5) can be summarized as follows: 

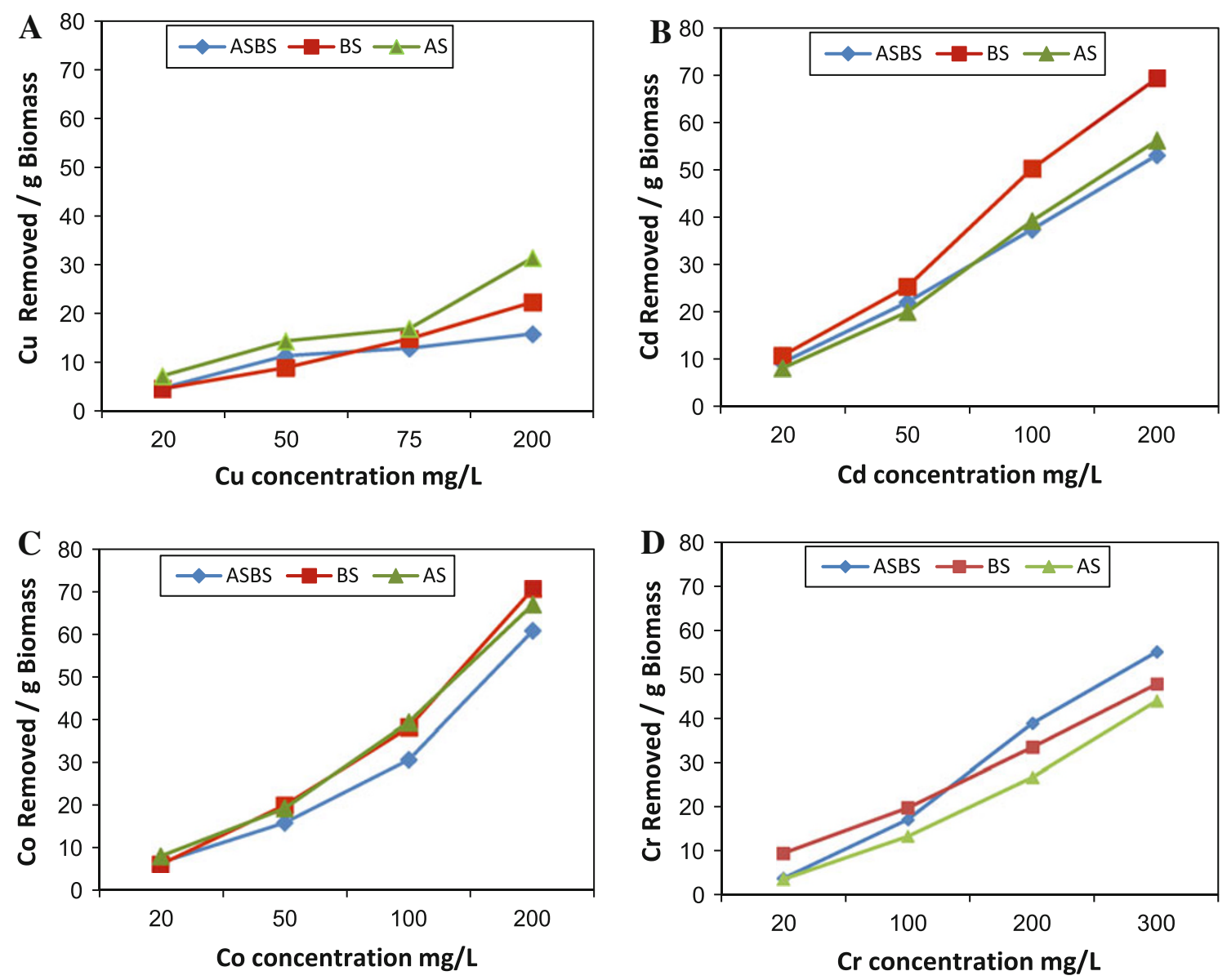

Fig. 4 Comparison among the three bioremediation technologies AS, ASBS and BS in the removal efficiency of a Cu, b Cd, $\mathbf{c ~ C o ~ a n d ~} \mathbf{d ~ C r}$ after 24-h exposure

1. As a general rule, removal of all the investigated metals was stimulated with increasing metal levels in the three investigated procedures reaching maximum efficiency at the highest applied concentration while COD removal decreased. Moreover, the removal of the investigated metals by the proposed technologies recorded the following order $\mathrm{Co}>\mathrm{Cd}>\mathrm{Cr}>\mathrm{Cu}$.

2. The highest $\mathrm{Cu}$ removal achieved (at $200 \mathrm{mg} / \mathrm{l}$ ) by the ASBS, BS and AS technologies recorded 15.84, 22.29 and $31.37 \mathrm{Cu} / \mathrm{g}$ biomass, respectively. Therefore, the magnitude of increasing $\mathrm{Cu}$ removal efficiency (RE \%) is $\mathrm{AS}>\mathrm{BS}>\mathrm{ASBS}$. On the contrary, COD removal under the highest $\mathrm{Cu}$ stress recorded 58.10, 57.82 and $38.16 \%$ using the ASBS, BS and AS technologies, respectively. Therefore, the magnitude of increasing $\mathrm{COD} \mathrm{RE} \%$ is ASBS $>\mathrm{BS}>\mathrm{AS}$.

3. The proposed technologies ASBS, BS and AS could achieve Cd removal (at $200 \mathrm{mg} \mathrm{Cd} / \mathrm{l}$ ) of 53.17, 69.36 and $56.25 \mathrm{mg} \mathrm{Cd} / \mathrm{g}$ sludge biomass, respectively. Therefore, $\mathrm{Cd}$ removal magnitude power order is $\mathrm{BS}>\mathrm{AS}>\mathrm{ASBS}$ technology. While COD removal was recorded as 23.12, 16.64 and $50.99 \%$ using the ASBS, BS and AS technology, respectively. Therefore, the magnitude of increasing COD $\mathrm{RE} \%$ is AS $>$ ASBS $>$ BS.

4. Co removal achieved (at $200 \mathrm{mg} / \mathrm{l}$ ) by the ASBS, BS and AS technologies recorded 60.93, 70.72 and $67.12 \mathrm{Co} / \mathrm{g}$ biomass, respectively indicating that $\mathrm{Co}$ removal efficiency by the three techniques is in the following order $\mathrm{BS}>\mathrm{AS}>\mathrm{ASBS}$ technology. COD removal under Co stress recorded 64.44, 48.44 and $55.16 \%$ using ASBS, BS and AS technology, respectively indicating magnitude of increasing COD RE \% as $\mathrm{ASBS}>\mathrm{AS}>\mathrm{BS}$.

5. Cr removal (at $300 \mathrm{mg} / \mathrm{l}$ ) recorded as 55.17, 47.89 and $44.04 \mathrm{mg} \mathrm{Cr} / \mathrm{g}$ using ASBS, BS and AS technology, respectively indicating an order of $\mathrm{ASBS}>\mathrm{BS}>\mathrm{AS}$ technology in $\mathrm{Cr}$ removal efficiency. COD removal under the highest $\mathrm{Cr}$ stress recorded 67.51, 10.51 and $51.05 \%$ using the ASBS, BS and AS technology, respectively. Therefore, the magnitude of increasing $\mathrm{COD} \mathrm{RE} \%$ is $\mathrm{ASBS}>\mathrm{AS}>\mathrm{BS}$. 

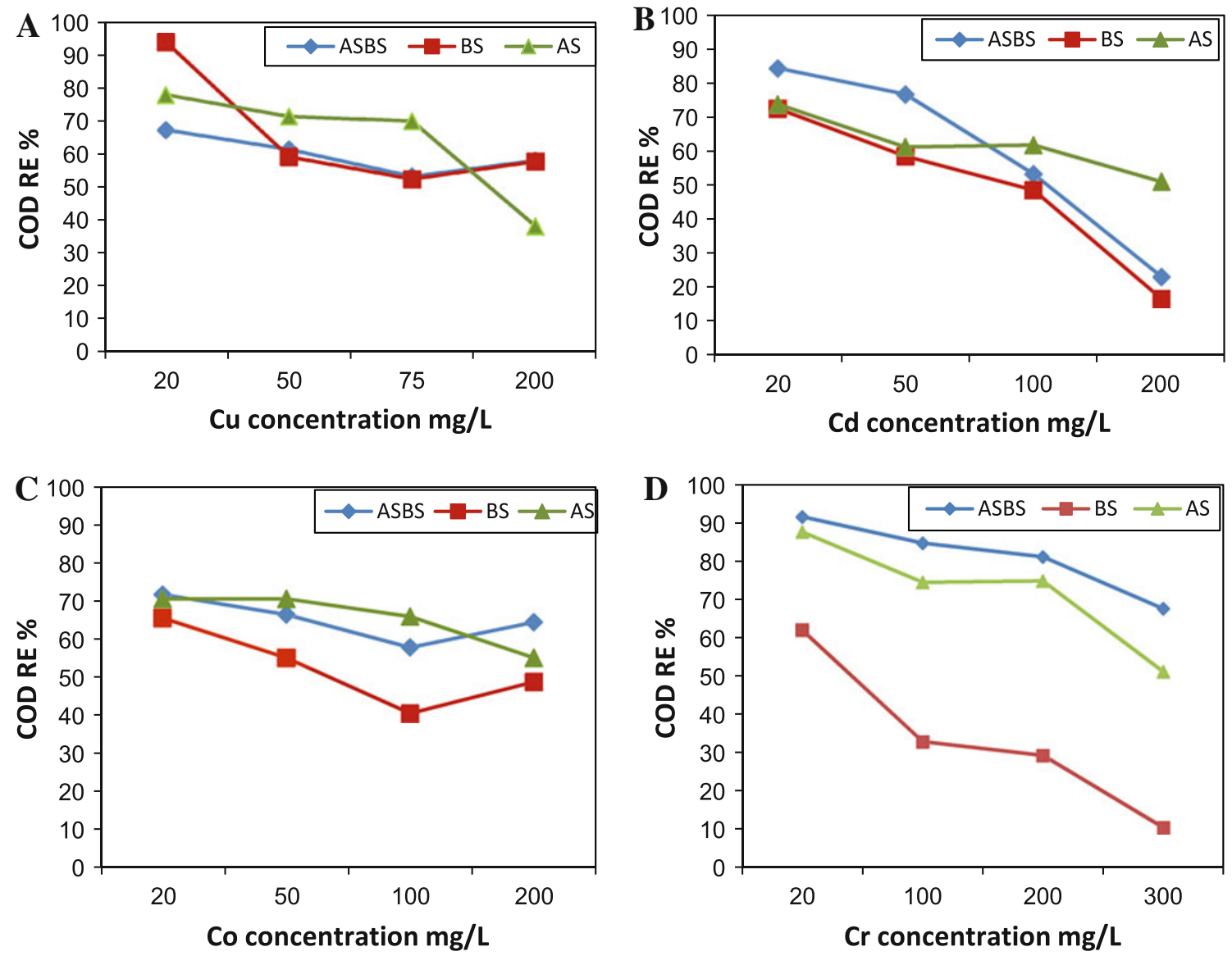

Fig. 5 Comparison among the three bioremediation technologies AS, ASBS and BS in the removal efficiency of COD in the presence of elevated levels of $\mathbf{a ~} \mathrm{Cu}, \mathbf{b} \mathrm{Cd}, \mathbf{c} \mathrm{Co}$ and $\mathbf{d} \mathrm{Cr}$ after 24-h exposure

Treatability bioassays of the contaminated wastewater in the presence of the four tested metals applied as individuals achieved the following points:

1. Native activated sludge (AS technology) exhibited the maximum efficiency in the removal of $\mathrm{Cu}$.

2. For $\mathrm{Cd}$ and Co removal, BS technology where acclimatized bacterial cultures were used, exhibited the highest efficiency followed by AS technology and ASBS technology with no significant variations.

3. Activated sludge amended with the acclimatized bacteria (ASBS technology) performed the highest efficiency for removing $\mathrm{Cr}$.

4. Activated sludge amended with the acclimatized bacteria (ASBS technology) performed almost the highest efficiency for removing COD from wastewater under the stress of all the investigated metals even under their highest levels.

Metal biosorption by microbial biomass is a well-known advanced biotechnological tool used for efficient removal of contaminant metals. Optimization tools of metal biosorption included many factors among which $\mathrm{pH}$ is the most important one (Comte et al. 2007) as well as the $\mathrm{C} / \mathrm{N}$ ratio of activated sludge (Yuncu et al. 2006) and temperature (Zouboulis et al. 2004). Acclimatization is a very important process for acquiring new advanced features of microorganisms that can be efficiently applied in metal biosorption. During the present study, using strains previously acclimated by exposing microbial biomass to metal concentration gradients (El. Bestawy et al. 2012) proved high efficiency in the enhancement of activated sludge performance for metals and organic matter removal even at high metal stresses. For example, Enterobacter sp. $\left(\mathrm{Cu}_{1}\right)$ acclimated to survive under high levels of $\mathrm{Cu}$ stress $(200 \mathrm{mg} / \mathrm{l})$ showed high efficiency for $\mathrm{Cu}(31.37 \mathrm{Cu} / \mathrm{g}$ biomass) and organic matter $(58.10 \%)$ removal compared to $2.93 \mathrm{mg} \mathrm{Cu} / \mathrm{g}$ achieved as the maximum removal by plain activated sludge (Principia et al. 2006). Similar results were obtained by manipulating metal binding capacity of Nocardia amarae cells to optimize the overall $\mathrm{Ni}, \mathrm{Cu}$ and $\mathrm{Cd}$ binding capacity of activated sludge (Kim et al. 2002). As in the present study the pure culture of 
Nocardia exhibited significantly higher metal sorption capacity than the activated sludge biomass attributed to the fact that the Nocardia cells growing at stationary phase have substantially more specific surface area than that of activated sludge. The metal sorption capacity of activated sludge increased proportionally with the amount of Nocardia cells present in the mixed liquor. Sirianuntapiboon and Ungkaprasatcha (2007) also reported efficient removal of $\mathrm{Pb}$ and $\mathrm{Ni}$ as well as organic matter by comparing acclimatized and un-acclimatized biosuldge.

Reductions in the COD removal with increasing metal concentrations during the present study are attributed mainly to the toxic effects and inhibition of the biodegradative microbes in the proposed treatment systems induced by the investigated metals at their elevated levels (Jefferson et al. 2001; Gikas 2007).

Treatment of wastewater effluent under mixed heavy metal stresses

Treatability study was also performed with mixtures of the four investigated metals with elevated concentrations after 24-h exposure. Three technologies were applied here included BS, where mixture (strains $\mathrm{Cu}_{1}, \mathrm{Cd}_{1}, \mathrm{Co}_{2}$ and $\mathrm{Cr}$ ) of the acclimatized bacteria was used, ASBS, where activated sludge supplied with the acclimatized bacteria was used and plain activated sludge (AS).

Heavy metal removals

As general trends for all the investigated metals and the three proposed treatment technologies, increasing metal concentrations from 5 to $75 \mathrm{mg} / \mathrm{l}$ enhanced their removal which was in the following order $\mathrm{Cu}<\mathrm{Cr}<\mathrm{Cd}<\mathrm{Co}$. The highest achieved $\mathrm{RE}(\mathrm{s}) \%$ of $\mathrm{Cu}, \mathrm{Cd}$, $\mathrm{Co}$ and $\mathrm{Cr}$ recorded were $6.61,16.58,27.58$ and $19.83 \mathrm{mg} / \mathrm{g}$ sludge, respectively using ASBS technology (Fig. 6a); 4.39, 22.89, 30.38 and $26.52 \mathrm{mg} / \mathrm{g}$ biomass, respectively using BS technology (Fig. 6b) and finally 7.09, 15.02, 21.08 and $18.58 \mathrm{mg} / \mathrm{g}$ biomass, respectively using AS technology (Fig. 6c).

The efficiency of using activated sludge under the stress of microbial inhibiting agents (i.e. heavy metals) is one of the issues with lots of environmental concern. Many factors affect the efficiency of activated sludge systems used for metal removal from contaminated media. $\mathrm{pH}$ considered as the most critical factor for microbial metal biosorption (Ozdemir et al. 2003; Sheng-lian et al. 2006; Congeevaram et al. 2007) which is mainly attributed to organism-specific physiology (Congeevaram et al. 2007). Other factors such as initial metal concentrations, activated sludge dosage, temperature, contact time (treatment duration), presence of other ions and organic materials in the bulk solutions
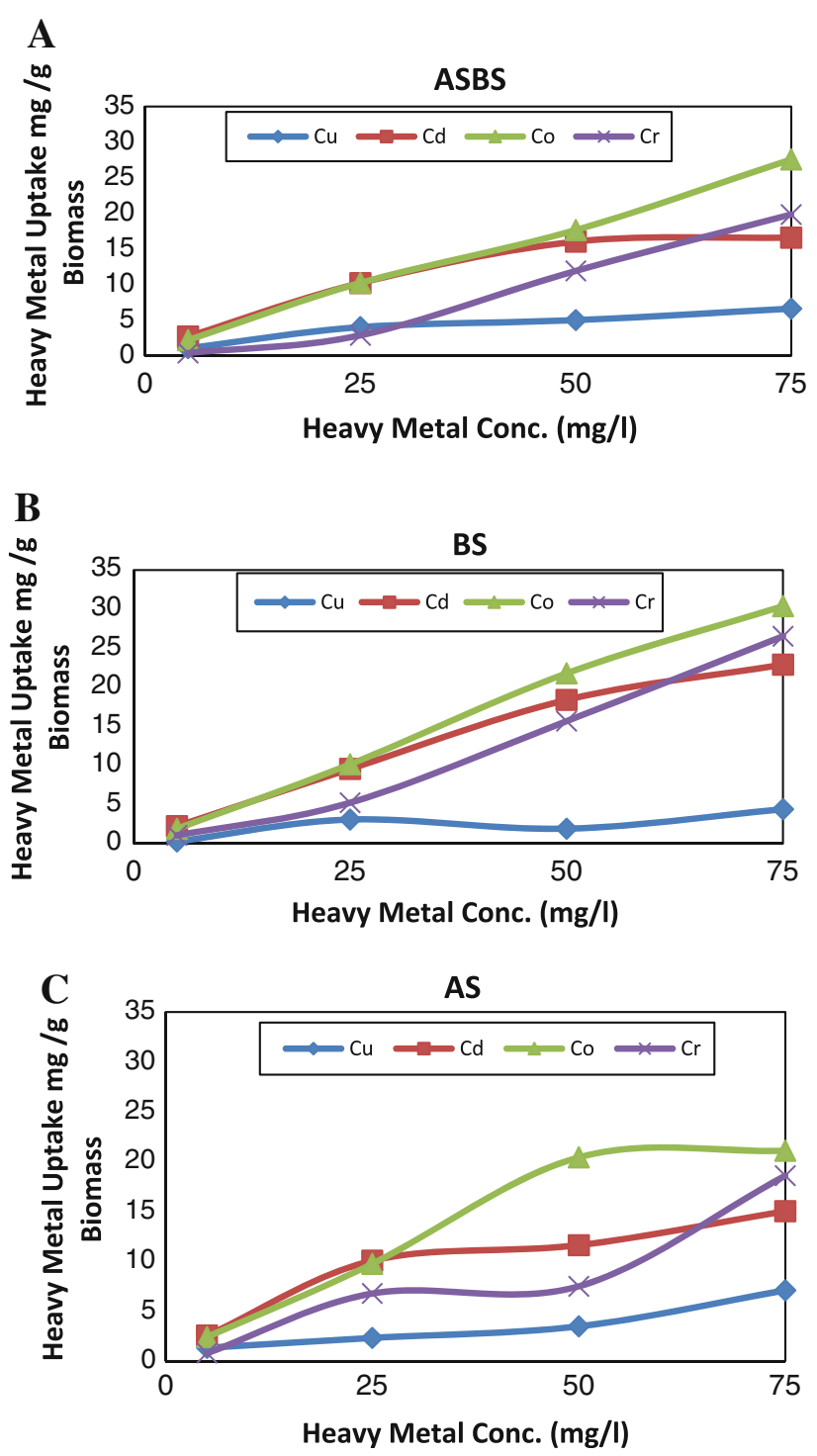

Fig. 6 Comparison among the removal efficiency of the investigated metals mixture of $\mathrm{Cu}, \mathrm{Cd}, \mathrm{Co}$ and $\mathrm{Cr}$ using the proposed a ASBS, b BS and c AS technology for 24-h exposure

(which may be in competition) could affect the efficiency of activated sludge for heavy metal removal. (Sheng-lian et al. 2006; Comte et al. 2007; Pamukoglu and Kargi 2007).

Bieszkiewicz and Hoszowski (1978) reported that activated sludge could tolerate up to $0.8,1.15$ and $20 \mathrm{mg} / \mathrm{l}$ only of $\mathrm{Cu}, \mathrm{Cr}$ III and $\mathrm{Cr}(\mathrm{VI})$, respectively after which the activated sludge experienced inferior purification and reduced intensity of respiration of its microorganisms. In another study, removal efficiency $\%$ of $\mathrm{Cu}, \mathrm{Cd}$ and $\mathrm{Cr}$ using activated sludge recorded only 80,62 and $46 \%$, respectively with initial concentrations of $0.8,20.9$ and $0.63 \mathrm{mg} / \mathrm{l}$ of the same metals (Petrasek and Kugelman 1983). Comparison with the present work indicated remarkable enhancement of the metal tolerance acquired 


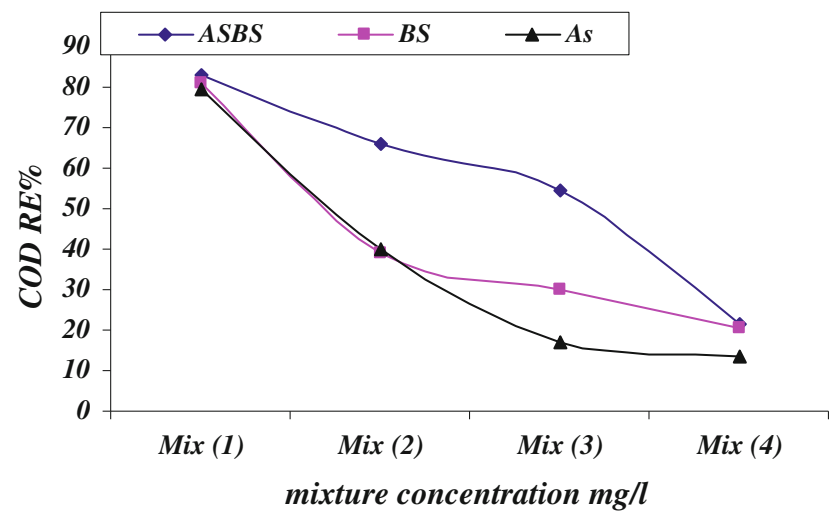

Fig. 7 Comparison among the removal efficiency of COD under mixed heavy metals stresses after 24-h exposure using the different treatment technologies ASBS, BS and AS

by the proposed activated sludge enabling it to handle high metal concentrations without reduction in its performance. It is also emphasized on the importance of optimizing the activated sludge performance through the amendments with acclimatized strains capable of handling high metal stresses.

\section{Organic matter (COD) removal}

Significant negative relations were clearly shown between metal concentrations and the RE \% of the effluent COD upon exposure to four heavy metal mixtures (each contains the four tested metals) with elevated concentrations for $24 \mathrm{~h}$. COD removal efficiencies recorded the following decreases with increasing metal concentrations from mixture 1 through 4; from 82.83 to $21.28 \%$ using ASBS technology; from 80.92 to $20.40 \%$ using BS technology and finally from 79.71 to 13.66 using AS technology (Fig. 7). Results revealed that the removal efficiencies of the COD were in the following order ASBS $>$ BS $>$ AS. Decreases in the COD RE \% with increasing metal concentrations are mainly attributed to the metal toxicity leading to inhibition on microbial growth and activity. These results are in agreement with Pamukoglu and Kargi (2007) who reported copper toxicity on COD removal which recorded much higher levels in the absence of $\mathrm{Cu}$ ions for all hydraulic residence time levels (HRTs) tested. They also indicated that copper toxicity on COD removal using activated sludge was partially eliminated by operation at high sludge ages (30 days) and 25-h HRTs.

\section{Conclusion}

Results of the present study proved that acclimated sludge bacteria acquired high resistance against the well-known toxic metals investigated and providing them efficient capabilities to remove high load of such metals from contaminated media. Augmentation of the activated sludge with metal-resistant bacteria isolated and identified during the present study is significantly enhanced its ability not only to deal with effluents highly contaminated with toxic heavy metals but also the organic load associated with most types of wastewater. Therefore, results highly recommend using the proposed bioaugmented activated sludge system which offers a low-cost, efficient and environmentally friendly technology for the treatment of either domestic or industrial or mixed type wastewater. It is considered the best choice to ensure high treatment efficiency and performance under metal stresses especially when industrial effluents are involved.

Conflict of interest The authors declare that they have no conflict of interest.

Open Access This article is distributed under the terms of the Creative Commons Attribution License which permits any use, distribution, and reproduction in any medium, provided the original author(s) and the source are credited.

\section{References}

Amer RA (2003) Regulation for heavy metal homeostasis genes in halophilic bacteria. PhD thesis, Faculty of Science, University of Alexandria, Egypt

Antonioli P, Lampis S, Chesini I, Vallini G, Rinalducci S, Zolla L, Righetti PG (2007) Stenotrophomonas maltophilia SeITE02, a new bacterial strain suitable for bioremediation of selenitecontaminated environmental matrices. Appl Environ Micobiol 73:6854-6863

Aoyama M, Nagumo T (1997) Effects of heavy metal accumulation in apple orchard soils on microbial biomass and activities. Soil Sci Plant Nutr 43:821-831

Ausubel FM, Brent R, Kingston RE, Moore DD, Seidam JG, Smith JA, Struhl K (1999) Short protocols in molecular biology, Willey, New York

Bieszkiewicz E, Hoszowski A (1978) Effect of copper and tri- and hexavalent chromium on the work of activated sludge. Acta Microbiol Poll 27(2):147-153

Borowski K (2004) An Operations overview and practical guide of microwave lab station. Inc. Milestone

Comte S, Guibaud G, Baudu M (2007) Biosorption properties of extracellular polymeric substances (EPS) towards $\mathrm{Cd}, \mathrm{Cu}$ and $\mathrm{Pb}$ for different $\mathrm{pH}$ values. J Hazard Mat 151:85-93

Congeevaram S, Dhanarani S, Park J, Dexilin M, Thamaraiselvi K (2007) Biosorption of chromium and nickel by heavy metal resistant fungal and bacterial isolates. J Hazard Mat 146:270-277

Costley C, Wallis FM (2001) Bioremediation of heavy metals in a synthetic wastewater using a rotating biological contactor. Wat Res 35(15):3715-3723

Drancourt M, Bollet C, Carlioz A, Martelin R, Gayral JP, Raoult D (2000) 16S ribosomal DNA sequence analysis of a large collection of environmental and clinical unidentifiable bacterial isolates. J Clin Microbiol 38:3623-3630

El. Bestawy E, Helmy S, Hussien H, Fahmy M (2012) Optimization and/or acclimatization of activated sludge process under heavy 
metals stress. World J Microbiol Biotechnol. doi:10.1007/ s11274-012-1225-9

Gikas P (2007) Kinetic responses of activated sludge to individual and joint nickel (Ni (II)) and cobalt (Co (II)): an isobolographic approach. J Hazard Mat 143:246-256

Gikas P (2008) Single and combined effects of nickel (Ni (II)) and cobalt (Co (II)) ions on activated sludge and on other aerobic microorganisms: a review. J Hazard Mat 159(2-3):187-203

Gikas P, Romanos P (2006) Effects of tri-valent (Cr(III)) and hexavalent $(\mathrm{Cr}(\mathrm{VI}))$ chromium on the growth of activated sludge. J Hazard Mat 133:212-217

Gong P (1997) Dehydrogenase activity in soil: a comparison between the TTC and INT assay under their optimum conditions. Soil Biol Biochem 29:211-214

Hall BK (1999) Homology, Introduction. Novartis Found Symp 222:1-4

He Z, Gao F, Sha T, Hu Y, He C (2009) Isolation and characterization of a $\mathrm{Cr}(\mathrm{VI})$-reduction Ochrobactrum sp. strain $\mathrm{CSCr}-3$ from chromium landfill. J Hazard Mat 163:869-873

Hussein HMA (1999) Influence of heavy metals on the biodegradation of hazardous wastewater. PhD thesis, Faculty of Science, University of Alexandria, Egypt

Jackson VA, Paulse AN, Bester AA, Neethling JH, Khan S, Khan W (2009) Bioremediation of metal contamination in the Plankenburg River, Western Cape, South Africa. Int Biodet Biodegrad 63:559-568

Jefferson B, Burgess JE, Pichon A, Harkness J, Judd SJ (2001) Nutrient addition to enhance biological treatment of gray water. Wat Res 35(11):2702-2710

Kelly JJ, Tate RL (1998) Effects of heavy metal contamination and remediation on soil microbial communities in the vicinity of a zinc smelter. J Environ Qual 27:609-617

Kelly CJ, Tumsaroj N, Lajoie CA (2004) Assessing wastewater metal toxicity with bacterial bioluminescence in a bench-scale wastewater treatment system. Water Res 38:423-431

Kim DW, Cha DK, Wang J, Huang CP (2002) Heavy metal removal by activated sludge: influence of Nocardi amarae. Chemo 46:137-142

Maidak BL, Larsen N, McCaughey MJ, Overbeek R, Olsen GJ, Fogel K, Blandy J, Woese CR (1994) The ribosomal database project. Nucleic Acids Res 22:3485-3487

Mathew M, Obbard JP (2001) Optimization of the dehydrogenase assay for measurement of indigenous microbial activity in beach sediments contaminated with petroleum. Biotechnol Lett 23:227-230

Nweke CO, Okolo JC, Nwanyanwu CE, Alisi CS (2006) Response of planktonic bacteria of New Calabar River to zinc stress. Afr J Biotechnol 5(8):653-658

Özbelge TA, Özbelge HÖ, Tursun M (2005) Effects of hydraulic residence time on metal uptake by activated sludge. Chem Eng Proc 44:23-32

Ozdemir G, Ozturk T, Ceyhan N, Isler R, Cosar T (2003) Heavy metal biosorption by biomass of Ochrobactrum anthropi producing exopolysaccharide in activated sludge. Biore Technol 90:71-74

Pamukoglu MY, Kargi F (2007) Copper (II) ion toxicity in activated sludge processes as function of operating parameters. Enzy Microb Technol 40:1228-1233
Petrasek AC, Kugelman IJ (1983) Metal removals and partitioning in conventional wastewater treatment plants. J Wat Poll Cont Fed 55:1183-1190

Principia P, Villab F, Bernasconib M, Zanardinia E (2006) Metal toxicity in municipal wastewater activated sludge investigated by multivariate analysis and in situ hybridization. Water Res 40:99-106

Qodah ZA (2006) Biosorption of heavy metal ions from aqueous solutions by activated sludge. Desalination 196:164-176

Rainey FA, Rainey NW, Kroppenstedt RM, Stackebrandt E (1996) The genus Nocardiopsis represents a phylogenetically coherent taxon and a distinct actinomycete lineage. Int J Syst Bacteriol 46:1088-1092

Sambrook J, Fritsch EF, Maniatis T (1989) Molecular Cloning. In: A laboratory manual, 2nd edn. Cold Spring Harbor Laboratory Press, Cold Spring Harbor

Sheng-lian L, Lin Y, Li-yuan C (2006) Biosorption behaviours of $\mathrm{Cu}_{2}^{+}, \mathrm{Zn}^{2+}, \mathrm{Cd}_{2}^{+}$and mixture by waste activated sludge. Trans Nonferrous Met Soc China 16:1431-1435

Shim JH, Shen JY, Kim MR, Lee CJ, Lim IS, No SM, Chi YT (2003) Determination of fungicide mancozeb by a bioassay method based on the inhibition of triphnyltetrazolium chloride reduction by isolate Bacillus sp. CMB03. Agric Chem Biotechnol 46(2):63-66

Sirianuntapiboon S, Ungkaprasatcha O (2007) Removal of $\mathrm{Pb}^{2+}$ and $\mathrm{Ni}^{2+}$ by bio-sludge in sequencing batch reactor (SBR) and granular activated carbon-SBR (GAC-SBR) systems. Biore Technol 98:2749-2757

Siunova TV, Siunov AV, Kochetkov VV, Boronin AM (2009) The $c n r$-Like operon in strain Comamonas sp. encoding resistance to cobalt and nickel. Russ J Genet 45(3):292-297

Thacker U, Rasesh P, Yogesh S, Datta M (2006) Hexavalent chromium reduction by Providencia sp. Proc Bioch 41:1332-1337

Valls M, Lorenzo VD (2002) Exploiting the genetic and biochemical capacities of bacteria for the remediation of heavy metal pollution. FEMS Microbiol Rev 26:327-338

Weddle CL, Jenkins D (1971) The viability and activity of activated sludge. Water Res 5:621-640

Weisburg WG, Barns SM, Pelletier DA, Lane DJ (1991) 16S ribosomal DNA amplification for phylogenetic study. J Bacteriol 173:697-703

Yaoa J, Tiana L, Wanga Y, Djaha A, Wanga F, Chena H, Sua C, Zhuanga R, Zhoua Y, Choib MMF, Bramantic E (2008) Microcalorimetric study the toxic effect of hexavalent chromium on microbial activity of Wuhan brown sandy soil: an in vitro approach. Ecotoxicol Environ Safety 69:89-95

Yuncu B, Sanin FD, Yetis U (2006) An investigation of heavy metal biosorption in relation to $\mathrm{C} / \mathrm{N}$ ratio of activated sludge. J Hazard Mater 137:990-997

Zaki S, Farag S (2010) Isolation and molecular characterization of some copper biosorped strains. Int $\mathrm{J}$ Environ Sci Tech 7(3):553-560

Zolgharnein H, Azmi MLM, Saad MZ, Mutalib AR, Mohamed CAR (2007) Detection of plasmids in heavy metal resistance bacteria isolated from the Persian Gulf and enclosed industrial areas Iranian. J Biotechnol 5(4):232-239

Zouboulis AI, Loukidou MX, Matis KA (2004) Biosorption of toxic metals from aqueous solutions by bacteria strains isolated from metal-polluted soils. Proc Bioch 39:909-916 